\title{
Usefulness of a Clinico-Biological Francois' Score in the Diagnosis of Acute Appendicitis: Experience of the University Hospital Center of Parakou, Benin
}

\author{
Montcho Adrien Hodonou ${ }^{1}$, Bio Tamou-Sambo'1, Salako Alexandre Allode1, \\ Roméo Romaric Gbédolo리 , Djifid Morel Séto ${ }^{1}$, Sélomé Romaric Tobomé2, \\ Moïse Francis Dossou3 ${ }^{3}$ Dodji Emile Mensah ${ }^{1}$
}

\footnotetext{
${ }^{1}$ Department of Surgery and Specialties, Teaching Hospital, Medicine School, University of Parakou, Parakou, Benin

${ }^{2}$ Saint John of God Hospital Center of Tanguieta, Tanguieta, Benin

${ }^{3}$ Teaching Hospital of Porto-Novo, Faculty of Health Science, University of Abomey Calavi, Cotonou, Benin

Email: `hodasm98@gmail.com
}

\begin{abstract}
How to cite this paper: Hodonou, M.A. Tamou-Sambo, B., Allode, S.A., Gbédolo, R.R., Séto, D.M., Tobomé, S.R., Dossou, M.F. and Mensah, D.E. (2018) Usefulness of a Clinico-Biological Francois' Score in the Diagnosis of Acute Appendicitis: Experience of the University Hospital Center of Parakou, Benin. Surgical Science, 9, 91-96. https://doi.org/10.4236/ss.2018.93009
\end{abstract}

Received: January 30, 2018

Accepted: March 6, 2018

Published: March 9, 2018

Copyright $(0) 2018$ by authors and Scientific Research Publishing Inc. This work is licensed under the Creative Commons Attribution International License (CC BY 4.0).

http://creativecommons.org/licenses/by/4.0/

\section{c) (i) Open Access}

\begin{abstract}
Introduction: Diagnostic wanderings of acute appendicitis are responsible for serious complications or abusive appendectomies. Existing Clinico-biological scores are efficient. Objective: To determine the diagnostic efficiency of François' score in acute appendicitis. Methodology: over 10 months, all the patients admitted in the CHUD-Parakou Emergency Department for pain in the right iliac fossa had been examined by resident students who calculated François' score. After verification by the surgeon, patients were put into three categories: category 1 score $\geq 2$; category 2 , score between -6 and 2; category 3 , score below -6 . Sensitivity and specificity were calculated. Results: out of 54 patients selected ( 29 men and 25 women), 29 were classified as group 1; 19 as group 2 and 6 as group 3. An ultrasound was performed in all patients in group 2, and signs in favor of appendicitis were found in 12 patients. Of the 41 appendicectomies performed, the histologic analysis of 33 operative specimens found a pathological appendix. Sensitivity, specificity and negative predictive value per group were $100 \%$. It has prevented almost in one every four patients (24.07\%) an abusive appendectomy. Conclusion: This score would reduce diagnostic wanderings and target patient groups for imaging studies.
\end{abstract}

\section{Keywords}

Acute Appendicitis, François Score, Sensitivity, Specificity, Resource-Limited Countries 


\section{Introduction}

Acute appendicitis is inflammation of the vermicular appendix. The most common non-traumatic abdominal surgical emergency, the incidence of acute appendicitis varies between $100-122$ cases per 100 thousand inhabitants in the West [1] [2].

In Africa, its frequency is $63.4 \%$ in the Central African Republic [3], $40.4 \%$ in Benin [4] and in Mali. It was ranked as the second non-traumatic surgical emergency after intestinal occlusion [5]. But in reality, the incidence of appendicectomy is greater than that of acute appendicitis, estimated at 40 - 60 appendectomies per 10,000 inhabitants [6] [7]. The rate of appendectomy on healthy appendix is therefore high, estimated at $15 \%-45 \%$ [2]. This discrepancy is related to the clinical polymorphism of the condition and its unpredictable clinical course. Because of the serious or even fatal complications that misunderstanding of this condition may cause, any suspicion of non-inverted appendicitis must be surgically performed: appendectomy. While in the West, CT scans have reduced diagnostic inaccuracies. In Africa, this complementary examination is still not very accessible. The advent of clinico-biological scores is an alternative to reduce diagnostic errors in our contexts. François' score is one of those many scores developed, which seems to us simple and feasible in our context. The objective of this study was to verify the reproducibility of the score and to verify its diagnostic efficiency.

\section{Patients and Methods}

This was a descriptive and analytical cross-sectional study covering a 10-month period from 01 July 2012 to 31 July 2013 taking into account patients aged 15 years and over admitted for acute localized pain in the iliac right fossa to the Emergency Department of the University Hospital of Borgou in Parakou. Those who had a palpable mass in the right iliac fossa or in whom it had not been possible to perform a leukocyte count had been excluded. The patients were examined by medical resident students. They were trained for the François score items [8] (Table 1) to identify the patients elligible for appendectomy. The surgeon confirmed the score and ranked each patient in the three categories offered by the François score on which the therapeutic indications depend (Table 2). The data has been studied in EPIINFO version 3.5.1. Sensitivity, specificity and diagnostic efficiency of the test were calculated.

\section{Results}

\subsection{Frequency and Socio-Demographic Characteristics}

We had received 670 patients during the period, 430 had been hospitalized including 128 cases of non-traumatic surgical acute abdomens. Among them, 54 cases of suspicion of acute appendicitis were retained, thus representing: 8.05\% of admissions (all pathologies combined); $12.56 \%$ of hospitalizations (all pathologies combined) and $42.19 \%$ of non-traumatic surgical acute abdomens. The 
Table 1. François score items.

\begin{tabular}{|c|c|c|c|}
\hline \multicolumn{2}{|c|}{ Signs in favor of appendicitis diagnosis } & \multicolumn{2}{|c|}{ Signs against diagnosis of appendicitis } \\
\hline Male & +2 & Female & -1 \\
\hline Age $\geq 50$ ans & +3 & Age $20-39$ ans & -1 \\
\hline Duration of symptoms & & Duration of symptoms & \\
\hline 36 hours & +2 & 3 days or plus & -3 \\
\hline 48 hours & +1 & Right rectal mass & -3 \\
\hline Existence of defense & +3 & No defense & -3 \\
\hline \multirow[t]{2}{*}{ Leukocytosis > 13 G/1 } & +2 & Leukocytosis < $10 \mathrm{G} / \mathrm{L}$ & -3 \\
\hline & & Genito-urinary Signs & -3 \\
\hline $\begin{array}{l}\text { Global Score: arithmetical su } \\
\text { When item values are not des }\end{array}$ & pe & points awarded is nil. & \\
\hline
\end{tabular}

Table 2. Interpretation and therapeutic attitude according to the François Score groups.

\begin{tabular}{|c|c|c|}
\hline Score $\geq+2$ & $-6<$ Score $<+2$ & Score $\leq-6$ \\
\hline $\mathbb{Z}$ & $\mathbb{Z}$ & $\mathbb{Z}$ \\
\hline $\begin{array}{l}\text { Very likely } \\
\text { appendicitis }\end{array}$ & $\begin{array}{c}\text { Doubt of appendicitis } \\
\text { diagnosis }\end{array}$ & $\begin{array}{l}\text { Appendicitis } \\
\text { very unlikely }\end{array}$ \\
\hline $\begin{array}{c}\text { To behave: } \\
\text { appendicectomy }\end{array}$ & $\begin{array}{c}\text { To behave: Abdominal } \\
\text { ultrasound }\end{array}$ & $\begin{array}{l}\text { To behave: } \\
\text { observation }\end{array}$ \\
\hline GROUP 1 & GROUP 2 & GROUP 3 \\
\hline
\end{tabular}

average age was 30.57 years (+/- 12.42) with extremes of 15 and 70 years. Twenty nine (29) were men and 25 women.

\subsection{Clinical Features}

Taking into account François' score, the group 1 was in the majority (53.7\%) (Table 3). The 19 patients in group 2 were ultrasonographically examined by the same sonographer and $12(63.2 \%)$ were confirmed as acute appendicitis", not "cc".

\subsection{Therapeutic Characteristics}

Patients in group 3 and 2 whose ultrasound was not in favor of appendicitis had been treated medically, for a total of 13 out of 54. Patients in group 1 and those in group 2 with ultrasound in favor of acute appendicitis were operated (appendectomy), 41 of the 54 patients. Thirty-three of the 41 patients who underwent surgery had an anatomopathological examination of the operative specimen. All the specimen analyzed were in favor of acute appendicitis (Table 4).

\subsection{Outcome Characteristics}

Group 3 patients and negative group 2 ultrasound patients, a total of 13 were followed for 3 months. None were readmitted for appendicitis. 


\subsection{Diagnostic Value of François' Score}

In our experience François' score diagnostic efficacy was $77.8 \%$, sensitivity was at $77.7 \%$, specificity was $100 \%$, positive predictive value $100 \%$ and negative predictive value $52.0 \%$. Taking the extreme groups, the sensitivity was $100 \%$ in group 1 and the negative predictive value was $100 \%$ in group 3 (Table 5).

\section{Discussion}

Acute appendicitis remains one of the most common digestive surgical conditions and one every ten people is at risk for acute appendicitis before the end of life [9]. Because of its clinical polymorphism the diagnosis sometimes remained a challenge before the era of the CT scan and even after [10]. However, acute appendicitis remains a fatal pathology. Mehinto DK et al. in 2004 reports $0.44 \%$ mortality in appendectomies [11]. It is therefore important to find simple and inexpensive diagnostic means for underprivileged areas such as ours. Drake and Flum [12] have established that the diagnostic means for acute appendicitis

Table 3. Patient distribution by group according to François' score.

\begin{tabular}{ccc}
\hline & Effective & Percentage \% \\
\hline Group 1 & 29 & 53.7 \\
Group 2 & 19 & 35.2 \\
Group 3 & 6 & 11.1 \\
Total & 54 & 100 \\
\hline
\end{tabular}

Table 4. Histological result of the surgical specimens.

\begin{tabular}{ccc}
\hline & Effective & Percentage \% \\
\hline Phlegmonous & 12 & 36.4 \\
Bluetongue & 10 & 30.3 \\
Gangrenous & 8 & 24.2 \\
Empyema & 2 & 6.1 \\
Perforated & 1 & 3 \\
Total & 33 & 100
\end{tabular}

Table 5. Statistical values of François' score according to the three groups.

\begin{tabular}{cccc}
\hline & Group $1(\mathrm{n}=29)$ & Group 2 $(\mathrm{n}=19)$ & Group 3 $(\mathrm{n}=06)$ \\
\hline Sensibility & 100 & 100 & - \\
Specificity & - & 100 & 100 \\
VPP & 100 & 100 & - \\
VPN & - & 100 & 100 \\
ED & 100 & 100 & 100 \\
\hline
\end{tabular}


depend on the experience of the practitioner, the location of the exercise and the facilities of that exercise site. These diagnostic means can range from simple use of scores to the CT scan. For Alvarado [13] the scores are suitable and must be an important tool to refine the diagnosis. The important role of the scores is thus demonstrated by all authors [12] [13] [14] [15]. Yu YR et al. [15] demonstrated that appendicitis diagnosis can be made in most patients without CT scan. Since the Alvarado score, several other clinical research Institutions have developed other scores to facilitate the diagnosis of acute appendicitis [16] [17]. François's score is one of them, and is easy to apply. In our study its sensitivity of $100 \%$ in group 1 and its negative predictive value of $100 \%$ in group 3 are comparable to 94.7\% and 97.4\% respectively found by Brigand C. et al. in 2009 in France [14]. Our results are also comparable to those of James DL et al. in Niamey (sensitivity $100 \%$ per group) [18]. The low specificity (around 50\%) found in the studies is the criticism of this score [9]. James DL et al. had false positive in group1 (3/63 cases) while all our group 1 cases where confirmed after surgical procedures. None of the patients in group 3, after three months of follow-up had been readmitted for appendicitis. Other authors [18] [19] have had to perform appendicitis in group 3. Our sample is weak compared to those authors. With such good sensitivity, this score is effective in the diagnosis at lower cost which is a significant benefit in resource-limited countries where the patient is forced to pay for all care and balance. This score, in our study, made it possible to avoid unnecessary appendectomies on healthy appendix in 13 out of 54 patients $(24.07 \%)$ representing nearly one every four patients with right iliac fossa pain. Similarly, this score was used to select those in whom imaging is necessary to confirm the diagnosis, thereby reducing the cost of managing acute appendicitis.

\section{Conclusion}

François score is simple, sensitive and specific tool for a proper diagnosis of acute appendicitis to avoid errors and inappropriate imaging demands. It has a great interest in developing countries.

\section{References}

[1] Ohmann, C., Franke, C., Kraemer, M. and Yang, Q. (2002) Neues zur Epidemiologie der akuten appendizitis. Der Chirurg, 73, 769-776.

https://doi.org/10.1007/s00104-002-0512-7

[2] Donnelly, N.J., Semmens, J.B., Fletcher, D. and Holman, C.D. (2001) Appendicectomy in West Australia: Profile and Trends 1981-1997. The Medical Journal of Australia, 175, 15-18.

[3] Zoguereh, D.D., Lemaitre, X., Ikoli, J.F., Delmont, J., Chamlian, A., Mandaba, J.L., et al. (2001) Acute Appendicitis at the National University Hospital in Bangui, Central African Republic: Epidemiologic, Clinical, Paraclinical and Therapeutics Aspects. Santé, 11, 117-125.

[4] Allodé, S.A., Mensah, A.E., Hodonou, M.A., et al. (2013) Résultat de l'appendicectomie au centre hospitalier départemental du Borgou-Alibori à Parakou au Nord-est du Bénin: étude de 164 cas. Medicale d Afrique Noire, 60, 6 p. 
[5] Konate, H. (2003) Abdomens aigus chirurgicaux dans le service de chirurgie générale et pédiatrique du CHU Gabriel Touré. Thèse médecine, Bamako, $72 \mathrm{p}$. http://www.keneya.net/fmpos/theses/2003/med/pdf/03M67.pdf

[6] Metman, E.H., Jougla, E., Maguim, P., et al. (1980) Morbidité digestive diagnostique chez l'adulte. Résultat d'une enquête épidémiologique. Gastroenterologie Clinique et Biologique, 4, 858-869.

[7] Tiret, L., Rotman, N., Hatton, F., et al. (1988) La chirurgie digestive en France. Une enquête épidémiologique nationale (1978-1982). Gastroenterologie Clinique et Biologique, 12, 354-360.

[8] François, Y., Bonvoisin, S., et al. (1991) Étude prospective d'un score prédictif d'appendicite dans les douleurs de la fosse iliaque droite. Devenir des patients à long terme. Gastroenterologie Clinique et Biologique, 15, 794-799.

[9] Bhangou, A., Soreide, K., Di Saverio, S., Assarsson, J.H. and Drake, F.T. (2015) Acute Appendicitis: Modern Understanding of Pathogenesis, Diagnosis and Management. The Lancet, 386, 1278-1287. https://doi.org/10.1016/S0140-6736(15)00275-5

[10] Jaeck, D., Balique, J.G., Beaulieux, J., et al. (2014) Rapport de la commission appendicite. E-mémoire de I Académie nationale de chirurgie, 13, 31-33.

[11] Mehinto, D.K., Olory-Togbe, J.L. and Padonou, N. (2004) Les complications d'appendicite pour appendicite aigue de l'adulte au Centre National Hospitalier et Universitaire (CNHU) de Cotonou. Medicale d Afrique Noire, 51, 361-365.

[12] Drake, F.T. and Flum, D.R. (2013) Improvement in the Diagnosis of Appendicitis. Advances in Surgery, 47, 299-328. https://doi.org/10.1016/j.yasu.2013.03.003

[13] Alvarado, A. (2016) How to Improve Clinical Diagnosis of Appendicitis in Limited Resources Settings. WJES, 11, 16-20.

[14] Brigand, C., Steinmetz, J.-P. and Rohr, S. (2009) De l'intérêt des scores en matière de diagnostic d'appendicite. Journal de Chirurgie, 146, 2-7. https://doi.org/10.1016/j.jchir.2009.08.001

[15] Yu, Y.R. and Shah, S.R. (2017) Can the Diagnosis of Appendicitis Be Made without Computed Tomography Scan? Advances in Surgery, 18 p.

[16] Andersson, M. and Andersson, R.E. (2008) The Appendicitis Inflammatory Response Score: A Tall for the Diagnosis of Acute Appendicitis That Outperforms the Alvarado Score. World Journal of Surgery, 32, 1843-1849. https://doi.org/10.1007/s00268-008-9649-y

[17] Fenyö, G., Lindberg, G., et al. (1997) Diagnostic Decision Support in Suspected Acute Appendicitis: Validation of a Simplified Scoring System. European Journal of Surgery, 163, 381-388.

[18] James, D.L., Hama, Y., Chaibou, M.S., Maarouf, M.I., Daddy, H., Illo, A., et al. (2014) Application du score de François dans le diagnostic des appendicites aiguës à l'Hôpital National de Niamey: à propos de 103 cas. Annales de P Université Abdou Moumouni, 17-A, 18-23.

[19] Sanchez, F. (2004) Valeur d'un score clinico-biologique pour le diagnostique de l'appendicite aiguë de l'adulte. Etude prospective de 202 cas. Thèse de Médecine, Université de Strasbourg (France), No. 43, 77 p. 